\title{
Minimum inhibitory concentration of essential oils against Staphylococcus aureus isolated from dogs with external otitis
}

\section{Concentração inibitória mínima de óleos essenciais contra Staphylococcus aureus isolados de cães com otite externa}

Geraldo Márcio Costa ${ }^{1 *}$; Ingrid Alexandre Prado2; Glei dos Anjos de CarvalhoCastro; Glaúcia Frasnelli Mian¹; Carlos Artur Lopes Leite1; Dircéia Aparecida Costa Custódio3; Roberta Hilsdorf Piccoli ${ }^{4}$

\section{Highlights}

The essential oils showed high antimicrobial action against Staphylococcus aureus.

Cinnamomum cassia and Cymbopogon citratus showed homogenous MIC for all isolates.

The essential oils tested have potential for therapeutic use in canine otitis.

\section{Abstract}

Canine otitis externa is a disease that affects the external acoustic meatus of about $20 \%$ of dogs at some point in life, without predilection for race, age, or sex. It is a multifactorial disease whose etiology involves several microorganisms, detaching Staphylococcus aureus. Antimicrobials are the basis for treating this illness; however, due to the increase in antimicrobial resistance, conventional drugs have become ineffective, requiring the search for alternative therapies. In this context, essential oils (EOs) have great therapeutic potential due to their broad antimicrobial action. This study aimed to evaluate the minimum inhibitory concentration (MIC) in order to measure the MIC50 and MIC90 of gentamicin and EOs of Eugenia caryophyllata, Thymus vulgaris, Cymbopogon winterianus, Cymbopogon citratus, and Cinnamomum cassia against 62 Staphylococcus aureus strains isolated from the external acoustic meatus of dogs. All EOs showed antibacterial action against the studied microorganisms, and their MIC50 and MIC90 were as follows: Eugenia caryophyllata, $2.42 \mathrm{mg} \mathrm{mL}^{-1}$ and $7.25 \mathrm{mg} \mathrm{mL}^{-1}$; Thymus vulgaris, $9.51 \mathrm{mg} \mathrm{mL}^{-1}$ and $22.94 \mathrm{mg}$ $\mathrm{mL}^{-1}$; Cymbopogon winterianus, $26.78 \mathrm{mg} \mathrm{mL}^{-1}$ and $157.79 \mathrm{mg} \mathrm{mL}^{-1}$; Cinnamomum cassia and Cymbopogon citratus, lower than 16.48 and $27.81 \mathrm{mg} \mathrm{mL}^{-1}$, with the same MIC for all isolates. The MIC50 and MIC90 found for gentamicin were $1 \mu \mathrm{g} \mathrm{mL}^{-1}$ and $8 \mu \mathrm{g} \mathrm{mL}^{-1}$. The MIC range found to antibiotic in this assay was 0.5

1 Profs., Faculdade de Zootecnia e Medicina Veterinária, Universidade Federal de Lavras, DCV, UFLA, Lavras, MG, Brazil. E-mail: gmcosta@ufla.br; gleicarv@yahoo.com.br; glauciamian@dmv.ufla.br; caca@ufla.br

2 Graduate Student, DCV, UFLA, Lavras, MG, Brazil. E-mail: ingrid.prado@hotmail

3 Researcher, DCV, UFLA, MG, Brazil. E-mail: dirceiacosta2017@gmail.com

4 Profa, Departamento de Ciência dos Alimentos, DCA, UFLA, MG, Brazil. E-mail: rob.hilsdorf@gmail.com

* Author for correspondence

Received: June 12, 2021 - Approved: July 25, 2021 
$\mu \mathrm{gL}^{-1}$ to $128 \mu \mathrm{g} \mathrm{mL}^{-1}$, and the isolates were classified as susceptible [48 strains $(77.41 \%)$ - MIC range of 0.5-4.0 $\mathrm{g} \mathrm{mL}^{-1}$ ], intermediate [eight strains (12.90\%) - (MIC $=8.0 \mu \mathrm{g} \mathrm{mL}^{-1}$ ], or resistant [six strains (9.68\%) $\left.\mathrm{MIC} \geq 16 \mu \mathrm{g} \mathrm{mL}^{-1}\right]$. The results, according to the in vitro assays, showed that resistance to gentamicin, one of the antimicrobials most commonly used to treat canine otitis, is present in the Staphylococcus aureus population evaluated. Additionally, the tested EOs have great potential for therapeutic use, however future studies should be carried out to evaluate their in vivo efficacy.

Key words: Phytotherapy. Otopathies. Antibacterials. Natural antimicrobials. MIC.

\section{Resumo}

A otite canina externa é uma doença que afeta o meato acústico externo de até $20 \%$ dos cães em algum período de suas vidas, sem predileção por raça, idade ou sexo. Trata-se de uma doença multifatorial que tem Staphylococcus aureus como um dos principais agentes etiológicos. Antimicrobianos constituem a base para o tratamento desta enfermidade, entretanto, devido ao incremento da resistência antimicrobiana, os fármacos convencionais tem se tornado pouco eficazes, o que requer a busca por terapias alternativas. Neste contexto, os óleos essenciais (OE) apresentam grande potencial terapêutico devido a sua ampla ação antimicrobiana. Este trabalho visou detectar a concentração inibitória mínima (CIM), a partir da qual foram obtidos os índices de MIC50 e MIC90 para a gentamicina e para os OE de Eugenia caryophyllata, Thymus vulgaris, Cymbopogon winterianus, Cymbopogon citratus e Cinnamomum cassia contra 62 Staphylococcus aureus isolados do meato acústico externo de cães otopatas. Todos os OE mostraram ação antibacteriana contra os microrganismos estudados e foram detectadas as seguintes CIM50 e CIM90: Eugenia caryophyllata, 2,42 $\mathrm{mg} \mathrm{mL}^{-1}$ e 7,45 $\mathrm{mg} \mathrm{mL}^{-1}$; Thymus vulgaris, 9,51 $\mathrm{mg} \mathrm{mL}^{-1}$ e 22,94 $\mathrm{mg}^{-1}$ $\mathrm{mL}^{-1}$; Cymbopogon winterianus, 26,78 $\mathrm{mg} \mathrm{mL}^{-1}$ e 157,79 $\mathrm{mg} \mathrm{mL}^{-1}$; Cinnamomum cassia e Cymbopogon citratus com CIM menores que 16,48 e 27,81 $\mathrm{mg} \mathrm{mL}^{-1}$, respectivamente já que estes apresentaram CIM única para todos os isolados testados. Para a gentamicina, foram obtidas CIM50 e CIM90 $1 \mu \mathrm{g} \mathrm{mL}^{-1}$ e 8 $\mu \mathrm{g} / \mathrm{m}$, respectivamente. Ademais, a faixa de CIM encontrada para o antibiótico variou de 0,5 a $128 \mu \mathrm{g} \mathrm{mL}^{-1}$, e os isolados foram classificados em susceptíveis [48 isolados $(77,41 \%)$ - CIM na faixa de 0,5-4 $\mathrm{gg} \mathrm{mL}^{-1}$ ], intermediários [8 isolados (12,90\%) - (CIM $=8 \mu \mathrm{g} \mathrm{mL}^{-1}$ ] e resistentes [6 isolados $(9,68 \%)-\mathrm{CIM} \geq 16$ ]. Os resultados encontrados mostraram que os micro-organismos testados tem potencial para desenvolver resistência antimicrobiana a terapêutica tradicional e que os $\mathrm{OE}$, de acordo com os resultados in vitro, apresentam potencial de uso terapêutico, entretanto futuros estudos devem ser realizados para avaliar a eficácia dos OE in vivo.

Palavras-chave: Fitoterapia. Otopatias. Antibacterianos. Antimicrobianos naturais. CIM.

\section{Introduction}

\section{Otitis externa is one of the} major diseases that affect the canine vestibulocochlear system, with 5 to $27 \%$ of animals showing clinical signs at some point in life. However, this frequency varies according to the geographic region (Griffin \& Aniya, 2017;
Kaimio, Saijonmaa-Koulumies, \& LaitinenVapaavuori, 2017). The causative factors of otitis have been classified as predisposing, primary, and perpetuating (Sykes, Nagle, \& White, 2014). Primary factors are the etiologic or primary cause of disease, while predisposing factors are anatomic or traumas regardless of sex or age, such as dogs with pendulous 
pinnae (Das, Pradhan, \& Behera, 2016; Sykes et al., 2014). Other predisposing factors associated with the disease are anatomic anomalies (auricular hypertrichosis, long or stenotic ear canals), excessive moisture (swimming, humidity), excessive cerumen production, and obstructive formations such as neoplasia or polyps. The factors classified as perpetuating are stenosis, dermal edema, fibrosis, mineralization, osteomyelitis, $\mathrm{pH}$ alteration, and secondary infections (Sykes et al., 2014).

Otitis externa is an inflammation of the ear canal. It has multifactorial causes such as trauma, ear canal neoplasia, foreign bodies, parasites, excessive cerumen production, and microorganisms (Penna, Varges, Martins, Martins, \& Lilenbaum, 2010; Oliveira et al., 2012; Sykes et al., 2014). Among those, the yeast Malassezia pachydermatis and the bacteria Staphylococcus pseudointermedius, S. aureus, Pseudomonas spp., Proteus spp., Escherichia coli, and Klebsiella spp. are relevant to the development of this illness. In most cases, the disease is caused by the association of different pathogens (Malayeri, Jamshidi, \& Zahraei, 2010; Petrov et al., 2013; Varshney, 2016; Ebani et al., 2017; Gheller, Meirelles, Figueria, \& Holsbach, 2017). The major clinical signs shown by dogs are ear pain, scratching, and head shaking, also showing a putrid odor related to exudate and behavioral alterations, irritability, and aggressiveness (Sykes et al., 2014). Erythema, tumefaction, swelling, dermatitis, otorrhea, and alopecia in the ear region are other common symptoms (Hnilica, 2012; Das et al., 2016).

The treatment of otitis externa usually requires antibiotic therapy. In this context, several commercial products used in Brazil have gentamicin in their composition.
However, resistance to conventional drugs and the emergence of multidrug-resistant isolates (MDR) has increased in recent years (Blair, Webber, Baylay, Ogbolu, \& Piddock, 2014; Scherer et al., 2018). Therefore, the search for alternative treatments is necessary to fight against resistant microorganisms associated with bacterial diseases. In this circumstance, essential oils (EOs) have great therapeutic potential. They are natural plant compounds yielded as complex secondary metabolites, volatile, and endowed with a strong odor (O'Bryan, Pendleton, Crandall, \& Ricke, 2015). Essential oils are usually composed of a mixture of 20 to 60 substances in different amounts and are divided into two groups: terpenes/terpenoids and aromatic and aliphatic compounds (Miguel, 2010; Swamy, Akhtar, \& Sinniah, 2016). The main compounds of EOs reflect their physical, chemical, and biological features, and their effects are dependent on the concentration and whether they are used alone or associated with other antimicrobials. In addition, they may also have antimicrobial action against viruses, fungi, and bacteria (Costa et al., 2005; Edris, 2007; Reichling, Schnitzler, Suschke, \& Saller, 2009; Nazzaro, Fratianni, Martino, Coppola, \& De Feo, 2013; Swamy et al., 2016; Orchard, \& Van Vuuren, 2017; Córdoba, Vivot, Szusz, \& Albo, 2019).

The strong antimicrobial action of EOs highlighted by several studies suggests the perspective of their use as an alternative to conventional drugs or even in association with them as synergistic agents to treat several infectious diseases, including canine otitis. Therefore, the present study aimed to determine the in vitro MIC the EOs of Eugenia caryophyllata (clove of India), Thymus vulgaris (Thyme), Cymbopogon winterianus (Citronella), 
Cymbopogon citratus (Lemongrass), and Cinnamomum cassia (Cassia cinnamon) and the antibiotic gentamicin against Staphylococcus aureus strains isolated from dogs affected by otitis externa.

\section{Material and Methods}

\section{Essential oils and antibiotic evaluated}

The EOs were produced and traded by FERQUIMA ${ }^{\oplus}$. They were diluted from 1:20 to $1: 640$ for the MIC assays, and the concentration in $\mathrm{mg} \mathrm{mL}^{-1}$ was determined according to the composition specified for each oil by the manufacturer.

The essential oils were evaluated in the following dilution ranges: Eugenia caryophyllata: $775 \mathrm{mg} \mathrm{mL}^{-1}$ to $1.21 \mathrm{mg} \mathrm{mL}^{-1}$; Thymus vulgaris: $460 \mathrm{mg} \mathrm{mL}^{-1}$ to $7.18 \mathrm{mg} \mathrm{mL}^{-1}$; Cymbopogon winterianus: $442 \mathrm{mg} \mathrm{mL}^{-1}$ to 6.91 $\mathrm{mg} \mathrm{mL}^{-1}$; Cymbopogon citratus: $890 \mathrm{mg} \mathrm{mL}^{-1}$ to $8.24 \mathrm{mg} \mathrm{mL}^{-1}$; and Cinnamomum cassia: $527.5 \mathrm{mg} \mathrm{mL}^{-1}$ to $13.9 \mathrm{mg} \mathrm{mL}^{-1}$. Additionally, the strains were subjected to MIC assays with the aminoglycoside gentamicin ranging from $2 \mu \mathrm{g} \mathrm{mL}^{-1}$ to $16 \mathrm{\mu g} \mathrm{mL}^{-1}$, as established by the Clinical and Laboratory Standards Institute [CLSI] (2018).

\section{Bacterial strains}

Sixty-two (62) Staphylococcus aureus strains belonging to the Bacterial Culture Collection of the Laboratory of Veterinary Microbiology of the Federal University of Lavras (UFLA) were used in this study. These strains were isolated from the auricular secretion of dogs with otitis externa and subjected to microbiological analysis in the laboratory from 2010 to 2015 . The strains were previously identified by phenotypic tests according to Koneman, Allen, \& Janda (2008) and maintained at $-70^{\circ} \mathrm{C}$ in brain heart infusion (BHI) (HIMEDIA ${ }^{\circledR}$ ) supplemented with $15 \%$ glycerol (MERCK ${ }^{\oplus}$ ) until their use.

\section{Determination of the Minimum Inhibitory Concentration (MIC)}

The MIC of the EOs was evaluated by the microdilution method in microplates containing Muller Hinton Broth (MHB) (HIMEDIA $\left.{ }^{\oplus}\right)$, using the methodology adapted from the CLSI (2018). For inoculum preparation, the isolates were thawed and incubated in $\mathrm{MHB}$ at $37^{\circ} \mathrm{C} / 18-24 \mathrm{~h}$. The bacterial concentration was adjusted in sterile saline solution according to the $0.5 \mathrm{McF}$ arland standard $\left(1.5 \times 10^{8}\right.$ UFC $\left.\mathrm{mL}^{-1}\right)$. The EOs were diluted to the concentrations mentioned above using dimethyl sulfoxide (DMSO)-MHB and added to the microplate wells in a serial dilution (1:20 -1:640). After dilutions, $10 \mu \mathrm{L}$ of bacterial inoculum was added to the wells, the plates were incubated at $37^{\circ} \mathrm{C}$ for $18-24 \mathrm{~h}$. The quality controls of the medium (wells with MHB and without inoculum) and the strain growth wells (containing MHB and DMSO) (MERCK) ${ }^{\circledR}$ (1:20), with bacteria and without antimicrobial agents, were used in all assays. The MIC results were based on visual evaluation (presence of turbidity and precipitate in each dilution). The MIC was defined as the highest EO dilution without bacterial growth. All assays were performed in duplicate, and the MIC was obtained by their arithmetic mean. The MIC50 and MIC90 values were defined as the lowest extract concentrations at which $50 \%$ and $90 \%$ of the clinical isolates were inhibited. The microbiological breakpoint of gentamicin was established according to the CLSI (2018). 
The bactericidal or bacteriostatic activity of the EOs against the isolates was evaluated by randomly choosing ten isolates at the dilution corresponding to the MIC. For this, $5 \mu \mathrm{L}$ of the medium of the wells corresponding to the MIC values were spread on plates containing Muller Hinton agar (HIMEDIA ${ }^{\circledR}$ ), which were incubated at $37^{\circ} \mathrm{C}$ for $18-24 \mathrm{~h}$. The absence of growth was interpreted as bactericidal activity, and its presence was interpreted as bacteriostatic activity of the EOs. Fisher's Exact Test was performed using the Epi-Info6.04b (1997) to evaluate the differences between the frequencies of bactericidal and bacteriostatic effects of the EOs, and a value of $p<0.05$ was considered statistically significant.

\section{Results and Discussion}

The MIC50, and MIC90 ranges found for the essentials oils and gentamicin against the tested isolates are summarized in Table 1. Regarding the EOs, only the MIC values were obtained since no standard breakpoints are established. The MIC values of Eugenia caryophyllata ranged from $1.21 \mathrm{mg} \mathrm{mL}^{-1}$ (1:640) to $19.37 \mathrm{mg} \mathrm{mL}^{-1}(1: 40) ;$ the MIC50 and MIC90 were $2.42 \mathrm{mg} \mathrm{mL}^{-1}$ and $7.25 \mathrm{mg}$ $\mathrm{mL}^{-1}$, respectively. The MIC values of Thymus vulgaris ranged from $7.18(1: 640) \mathrm{mg} \mathrm{mL}^{-1}$ to $57.5 \mathrm{mg} \mathrm{mL}^{-1}$ (1:80); the MIC50 and MIC90 were established as $9.51 \mathrm{mg} \mathrm{mL}^{-1}$ and $22.94 \mathrm{mg}$ $\mathrm{mL}^{-1}$, respectively. Cymbopogon winterianus showed an MIC range from $13.82 \mathrm{mg} \mathrm{mL}^{-1}$ (1:320) to $22.13 \mathrm{mg} \mathrm{mL}^{-1}(1: 20)$; the MIC50 and MIC90 were $26.78 \mathrm{mg} \mathrm{mL}^{-1}$ and $157.79 \mathrm{mg}$ $\mathrm{mL}^{-1}$, respectively. The EOs of Cinnamomum cassia and Cymbopogon citratus showed, at their highest dilutions against all isolates (1:640), MIC values corresponding to 16.48 $\mathrm{mg} \mathrm{mL}^{-1}$ and $27.81 \mathrm{mg} \mathrm{mL}^{-1}$, respectively, while their MIC50 and MIC90 values were lower than these MIC values. One of the isolates classified as gentamicin-resistant showed the highest MIC for Eugenia caryophyllata and Cymbopogon winterianus (Supplementary Table 1).

The MIC values for gentamicin ranged from $0.5 \mu \mathrm{g} \mathrm{mL}^{-1}$ to $128 \mu \mathrm{g} \mathrm{mL}^{-1}$ and were classified according to the CLSI (2020) as susceptible $(77.41 \%$ of strains - MIC range 0.5-4 $\left.\mathrm{gg} \mathrm{mL}^{-1}\right)$, intermediate $(12.90 \%-\mathrm{MIC}=$ $\left.\mu \mathrm{g} \mathrm{mL}^{-1}\right)$, or resistant $\left(9.68 \%-\mathrm{MICs} \geq 16 \mu \mathrm{g} \mathrm{mL}^{-1}\right)$. The MIC results for gentamicin showed four dilution values beyond its breakpoint, while the MIC50 and MIC90 were within the susceptible and intermediate categories, respectively.

All the essential oils showed heterogeneous bacterial activity varying according the isolate assayed, however none showed bactericidal action in the dilution corresponding to the MIC against all tested isolates (Supplementary Table 1).

Canine otitis externa is one of the most frequent illnesses in veterinary clinics, and its treatment is usually based on the administration of topic or systemic antimicrobials. However, therapeutic failures may occur, especially due to multidrugresistant (MDR) microorganisms (Bourély et al., 2019). Nowadays, the increase in resistance among pathogens that cause diseases in humans and animals is a worldwide concern that demands studies focusing on alternative treatments, and EOs have shown great potential for this purpose. These substances are secondary plant metabolites constituted by a mix of organic compounds, ranging from 20 to 60 components with low molecular weight and 
at different concentrations. Several EOs have been screened as antimicrobials and are generally regarded as safe (GRAS) as there are no reports of bacterial resistance even when used for a long time (Dal Pozzo et al., 2011; Lang, \& Buchbauer, 2012; Akhtar, Degaga, \& Azam, 2014; Andrade, Barbosa, Probst, \& Fernandes Júnior, 2014; Al-Mariri \& Safi, 2014; Lopez-Romero, González-Ríos, Borges, \& Simões, 2015; O'Bryan et al., 2015).

\section{Table 1}

Minimum Inhibitory Concentration (MIC) of essential oils and gentamicin against 62 Staphylococcus aureus strains isolated from dogs with otitis externa

\begin{tabular}{|c|c|c|c|c|c|}
\hline Antimicrobials & $\begin{array}{c}\mathrm{MIC} \\
\left(\mathrm{mg} \mathrm{mL}^{-1}\right)\end{array}$ & $\begin{array}{l}\text { Number of } \\
\text { strains (\%) }\end{array}$ & $\begin{array}{c}\text { MIC50 } \\
\left(\mathrm{mg} \mathrm{mL}^{-1}\right)\end{array}$ & $\begin{array}{c}\mathrm{MIC90} \\
\left(\mathrm{mg} \mathrm{mL}^{-1}\right)\end{array}$ & Profilea \\
\hline \multirow{6}{*}{ Gentamicin* } & $0.5 \mu \mathrm{g} \mathrm{mL}^{-1}$ & 29 (46.77\%) & & & Susceptible \\
\hline & $2 \mu \mathrm{gL}^{-1}$ & 13 (20.96\%) & & & Susceptible \\
\hline & $4 \mu \mathrm{g} \mathrm{mL}^{-1}$ & $6(9.67 \%)$ & $1 \mu \mathrm{g} \mathrm{mL}^{-1}$ & $8 \mu \mathrm{g} \mathrm{mL}^{-1}$ & Susceptible \\
\hline & $8 \mu \mathrm{g} \mathrm{mL}^{-1}$ & $8(12.90 \%)$ & & & Intermediate \\
\hline & $16 \mu \mathrm{g} \mathrm{mL}^{-1}$ & 5 (8.06\%) & & & Resistant \\
\hline & $128 \mu \mathrm{g} \mathrm{mL}^{-1}$ & $1(1.61 \%)$ & & & Resistant \\
\hline \multirow{5}{*}{ Eugenia caryophyllata } & 1.21 & $14(22.58 \%)$ & & & - \\
\hline & 2.42 & 17 (27.42\%) & & & - \\
\hline & 4.84 & 19 (30.64\%) & 2.42 & 7.25 & - \\
\hline & 9.068 & 10 (16.12\%) & & & - \\
\hline & 19.37 & 2 (3.22\%) & & & - \\
\hline \multirow{4}{*}{ Thymus vulgaris } & 7.18 & 25 (40.32\%) & & & - \\
\hline & 14.37 & 19 (30.64\%) & 9.51 & 22.94 & - \\
\hline & 28.75 & 14 (22.58\%) & & & - \\
\hline & 57.5 & $4(6.45 \%)$ & & & - \\
\hline \multirow{5}{*}{ Cymbopogon winterianus } & 13.82 & 12 (19.35\%) & & & - \\
\hline & 27.65 & 20 (32.25\%) & & & - \\
\hline & 55.31 & 14 (22.58\%) & 22.78 & 157.79 & - \\
\hline & 110.62 & 7 (11.29\%) & & & - \\
\hline & 221.25 & 9 (14.51\%) & & & - \\
\hline Cinnamomum cassia & 16.48 & 62 (100\%) & $<16.48$ & & - \\
\hline Cymbopogon citratus & 27.81 & 62 (100\%) & $<27.81$ & & - \\
\hline
\end{tabular}

* Gentamicin results are expressed in $\mu \mathrm{g} \mathrm{mL} \mathrm{m}^{-1}$.

a The susceptibility profile was found only to gentamicin according to the CLSI. 
Although the use of EOs as antimicrobials has been recognized since the dawn of civilization, the scientific interest in these substances as an alternative to antibiotics in the fight against human and animal pathogens has increased due to the MDR phenomenon (Lopez-Romero et al., 2015; O'Bryan et al., 2015). The antibacterial activity of EOs has thus been explored, and several mechanisms have already been reported, such as damage to the cell membrane, causing the loss of selective permeability, the collapse of the proton pump and lysis of the microorganism, and cytoplasmic coagulation (Gustafson et al., 1998; Lopez-Romero et al., 2015; Swamy et al., 2016).

In the present study, the aminoglycoside gentamicin was tested in the MIC assays. This antimicrobial is present in several commercial drugs used in Brazil for the topical therapy of canine otitis externa. The MIC assays showed that 24 (19\%) isolates were not susceptible to this antibiotic and were classified as resistant or intermediate strains, being very close to wildtype strains (Bourély et al., 2019). Although the gentamicin concentrations in commercial products used to treat canine otitis are higher than the concentrations evaluated in the MIC assay, our results showed that its use might be a negative factor due to the increase in the selective pressure against resistant strains of $S$. aureus circulating in the canine population. Furthermore, it can become a serious public health concern due to the relationship between dogs and humans and the risks of interspecies infections. Interestingly, it was observed that one isolate classified as gentamicin-resistant showed the highest MIC for two EOs, allowing us to infer that this strain is potentially MDR since the non-susceptibility to one or more antimicrobials of three or more antimicrobial classes characterizes multidrug resistance (Magiorakos et al., 2012).

In the last decade, a faster resistance propagation among bacterial pathogens has been observed due to the excessive use of antibiotics, limiting the efficacy of treatment of several infectious diseases in animals and humans (Lopez-Romero et al., 2015). Previous studies have suggested a high resistance to gentamicin by $S$. aureus isolated from skin and nosocomial infections in humans (Caraciolo, Maciel, Santos, Rabelo, \& Magalhães, 2012; Bortolin, Bidossi, De Vecchi, Avveniente, \& Drago, 2017). Moreover, S. aureus has several features related to antimicrobial resistance, including biofilm formation, which impairs the treatment of infected hosts (Swamy et al., 2016). Although biofilm formation was not evaluated in this study, this virulence factor is already known among $S$. aureus strains isolated from canine otitis, increasing the antimicrobial resistance and pathogenicity (Moreira et al., 2012; Lee et al., 2019).

All EOs tested in this study showed MIC variations for the different strains, except C. cassia and C. citratus, which showed homogeneous results, with all strains showing the same MIC and stopping microbial growth in the last dilution (1:640). The differences in the antimicrobial action of the EOs tested could be related to their different compounds. The composition and antimicrobial effects of EOs can be influenced by the season, geographic region, soil type, plant part used, harvest time, and weather conditions (Castro, Barbosa, Leal, Souza, \& Nazareno, 2007; Celiktas et al., 2007; Kamatou et al., 2008; Swamy et al., 2016). Despite the variation in the MIC ranges assessed, the MIC50 values found for all EOs and for the antibiotic 
against the isolates corresponded to the lowest concentrations tested, whereas the MIC90 showed greater variability. The MIC50 found showed that irrespective of the OEs of Eugenia caryophyllata, Thymus vulgaris, and Cymbopogon winterianus, as well as the antimicrobial gentamicin, almost all were able to inhibit $50 \%$ of the bacterial strains tested at low concentrations, corresponding to the two highest dilutions tested. Regarding these same EOs, the MIC90 values were approximately three times higher than the MIC50, except for Cymbopogon winterianus, which showed a higher ratio between the MIC50 and MIC90 values (6.92). Future assays are necessary to evaluate the MIC50 and MIC90 of C. cassia and $C$. citratus as these EOs showed MIC values in the highest dilution tested against all isolates. The MIC90 found for gentamicin was within the intermediate category, highlighting the possible development of antimicrobial resistance by $S$. aureus isolated from otitis to this antibiotic.

Regarding C. cassia, several studies have also shown the antimicrobial action of cinnamaldehyde against Staphylococcus spp. isolated from bovine mastitis (Baskaran, Kazmer, Hinckley, Andrew, \& Venkitanarayanan, 2009; Dal Pozzo et al., 2012). Firmino et al. (2018) found that the major active component of the EO of $C$. cassia with antibacterial activity against $S$. aureus ATCC6538 was cinnamaldehyde, with the MIC ranging from $250 \mu \mathrm{g} \mathrm{mL}^{-1}$ to $500 \mathrm{\mu g} \mathrm{mL}^{-1}$. In contrast, the MIC of the EO of C. cassia observed in our study ( $<16.48 \mathrm{mg} \mathrm{mL}^{-1}$ ) showed a higher value. This difference can be explained by the fact that we used crude EO, generally composed of a mixture of 20 to 60 substances (Swamy et al., 2016), resulting in the dilution of its antimicrobial components. Additionally, this difference could be associated with the different bacterial strains used in this study as well as the origin of the EO. Netopilova et al. (2020) demonstrated the synergistic effect of C. cassia with 8-hydroxyquinoline against $S$. aureus, highlighting the ability of $C$. cassia to inhibit this bacterial species and showing that the concentration used in this study can be later optimized to evaluate whether the in vitro antimicrobial effect will be repeated in vivo.

The EO of $C$. citratus has been used as a food preservative agent, as an inhibitor of biofilm formation in different environmental niches, and as an antifungal and antibacterial. This EO acts on membrane permeability, inhibiting essential activities necessary to bacterial survival as well as quorum sensing, preventing biofilm formation in dental caries, and is also present in the food industry (Ekpenyong \& Akpan, 2015; Oliveira et al., 2017; Ortega-Cuadros, Tofiño-Rivera, Merini, \& Martínez-Pabon, 2018). Its main antimicrobial components are citral (alpha and beta), geranial, and myrcene, which have analgesic action. Its effects are dependent on the concentration and can be improved by the association of its compounds (Aiemsaard, Aiumlamai, Aromdee, Taweechaisupapong, \& Khunkitti, 2011; Oliveira et al., 2017; OrtegaCuadros et al., 2018). In our study, the EO of C. citratus inhibited bacterial growth at the concentration of $27.81 \mathrm{mg} \mathrm{mL}^{-1}$. However, different concentration ranges aiming at an optimal dose could be assayed to kill S. aureus since its lipophilic activity is increased over higher concentrations (Córdoba et al., 2019). Other studies have demonstrated that the EO of C. citratus has a good antimicrobial effect against bacteria isolated from turtle and human newborns (Silva et al., 2018; Oliveira et al., 2019). Sahal et al. (2020) reported this oil 
as a potential antifungal and antibiofilm agent that can be used to prevent contamination in silicone rubber prostheses and medical devices.

The EO of Thymus vulgaris has been reported as an antimicrobial, antiseptic, and antioxidant, and its main action seems to be in the cell membrane, changing the permeability due to its lipolytic action (Lorenzi, \& Matos, 2002; Suzuki, Flemming, \& Traad, 2008). The main components of Thymus vulgaris are thymol, p-cymene, linalool, carvacrol, caryophyllene oxide, and E-caryophyllene. The proportion of its majoritarian compounds varies according to the geographic region, season, and plant part used (Benameur, Gervasi, Pellizzeri, Pl'uchtová, Tali-Maama, Assaous, \& Ben-Mahdi, 2018).

In our study, the EO of Thymus vulgaris showed MIC50 and MIC90 values of 9.51 $\mathrm{mg} \mathrm{mL}^{-1}$ and $22.94 \mathrm{mg} \mathrm{mL}^{-1}$, respectively. Likewise, Kot, Wierzchowska, Grużewska, \& Lohinau (2017) found MIC values ranging from $0.012 \%$ to $0.048 \%$ against methicillinresistant Staphylococcus aureus (MRSA) isolated from humans and demonstrated that this EO reduced biofilm formation by up to $85 \%$. Nostro et al. (2007) also described the inhibitory action of the EO of T. vulgaris on biofilms, highlighting its positive effect against biofilm-producing strains. Another study demonstrated the antimicrobial action of Thymus vulgaris against $S$. aureus isolated from canine otitis at the MIC of $17.86 \mu \mathrm{g} \mathrm{mL}$ 1 , a concentration below the value obtained in our study, probably due to the different oil composition (Ebani et al., 2017). In another study, Benameur et al. (2018) showed that the components extracted from this EO have a good antimicrobial effect against MDR enterobacteria at MIC values ranging from
2.87 to $11.5 \mu \mathrm{g} \mathrm{mL}-1$. Additionally, this EO showed good antimicrobial activity against Staphylococcus and Malassezia isolated from canine dermatitis (Ebani et al., 2020).

The MICs found for the EO of Cymbopogon winterianus showed a wide variation, with MIC50 and MIC values of 22.78 $\mathrm{mg} \mathrm{mL}^{-1}$ and $157.79 \mathrm{mg} \mathrm{mL}^{-1}$, respectively. This EO has been recognized as an effective antibacterial against $S$. aureus isolated from food as well as against resistant bacteria with variable MICs, similar to the results observed in this study (Oussalah, Caillet, Saucier, \& Lacroix, 2006.; Brugnera, Liveira, \& Piccoli, 2011; Lertsatitthanakorn, Taweechaisupapong, Aarunyanart, Aromdee, \& Khunkitti, 2010; Hussain, Anwar, \& Nigamet, 2011; Wattanasatcha, Rengpipat, \& Wanichwecharungruang, 2012). Imane et al. (2020) found an MIC of $8.07 \mathrm{mg} \mathrm{mL}^{-1}$ against MRSA. However, this concentration was unable to kill the bacteria.

The EO of Eugenia caryophyllata has eugenyl acetate, B-caryophyllene, and eugenol as its components, with the last being found at higher concentrations. It has bactericidal, fungicidal, and nematicidal activity, acting mainly on the cell membrane, denaturing proteins, reacting with lipids, and changing membrane permeability (Briozzo, Núncez, Chirite, Herszage, \& D'aquino, 1989; Cardoso et al., 2007). In our study, Eugenia caryophyllata showed different MIC values against the tested strains, with MIC50 and MIC values of $2.42 \mathrm{mg}$ $\mathrm{mL}^{-1}$ and $7.25 \mathrm{mg} \mathrm{mL}^{-1}$, respectively. Fu, Zu, Chen, Wang, Sun and Efferth (2007) evaluated the antimicrobial effect of this EO and found an MIC of $0.125 \%$ against S. aureus, lower than the MIC observed in this study. Al-Shabib, Husain, Ahmad and Baig (2017) demonstrated that eugenol, the main component of the EO 
of Eugenia caryophyllata, reduces biofilm production and the expression of other virulence genes in MRSA isolated from food handlers. Likewise, Yadav, Chae, Im, Chung, \& Song (2015) demonstrated the reduction of in vitro and in vivo biofilm formation against $S$. aureus isolated from different origins.

The microbicidal action of all EOs in the MIC dilution showed heterogeneity, which can be associated with individual susceptibility characteristics of the isolates and the different compositions of each EO. Regarding the bactericidal action of the EOs, Cymbopogon winterianus and Cinnamomum cassia seem to be more efficient as they could kill $S$. aureus at the lowest dilutions compared to the other EOs $(p<0.05)$. The bacteriostatic effect was found predominantly among the EOs of Thymus vulgaris, Eugenia caryophyllata, and Cymbopogon winterianus, without significant differences in their frequencies $(p>0.05)$. However, the bactericidal effect may occur at EO concentrations higher than the MIC.

Differences in the antimicrobial potency of the EOs were observed in relation to previous studies, which can be explained by several factors, such as the site of isolation, the size of the inoculum, the growth stage of the microorganism, the oil compounds, oil solubility, and the oil diluent used (Hammer, Carson, \& Riley, 1999; Opalchenova \& Obreshkova, 2003). Regarding the oils diluent, DMSO or Tween $20 \%$ can influence bacterial growth or membrane permeability due to the synergistic or antagonistic action of the EOs (Nascimento et al., 2007). Control tests were used in our study, demonstrating that DMSO did not show inhibitory action against the tested microorganisms.

Our study highlighted the potential of EOs in the treatment of canine otitis caused by
S. aureus. However, it should be emphasized that these data refer to an in vitro assay and that the inhibitory concentration of an antimicrobial at the site of infection could be different due to intrinsic pharmacological characteristics (Kahlmeter et al., 2003). Also, it should be highlighted that canine otitis has multifactorial causes and involves several mycotic, bacterial, and parasitic pathogens. Thus, additional studies including other agents of importance to its etiology are necessary within a clinical use perspective. Finally, future in vivo studies will be necessary to confirm the results obtained in vitro as well the perspective of developing new antimicrobial drugs derivate from EOs or their extracts against $S$. aureus, one of the main multidrug-resistant microorganisms (Bourély et al., 2019).

\section{Conclusions}

All EOs screened here showed antimicrobial action against $S$. aureus. Future in vivo studies will be necessary to confirm the results obtained in vitro as well the perspective of developing new antimicrobial drugs based on EOs or their extracts against the pathogens that cause canine otitis and, eventually, their side effects.

Our research addressed a public health concern associated with the possible selective pressure over $S$. aureus isolated from otitis externa in dogs due to gentamicin, highlighting the need for continuous surveillance and studies focusing on new alternative treatments, as shown here.

Acknowledgments

We thanks the support provided by FAPEMIG (Grants project APQ 02025/13 and BPD-00261/14). 


\section{References}

Aiemsaard, J., Aiumlamai, S., Aromdee, C., Taweechaisupapong, S., \& Khunkitti, W. (2011). The effect of lemongrass oil and its major components on clinical isolate mastitis pathogens and their mechanisms of action on Staphylococcus aureus DMST 4745. Research in Veterinary Science, 91(3), 31-37. doi: 10.1016/j.rvsc. 2011.01.012

Akhtar, M. S., Degaga, B., \& Azam, T. (2014). Antimicrobial activity of essential oils extracted from medicinal plants against the pathogenic microorganisms: "a review". Biological Sciences and Pharmaceutical Research, 2(1), 1-7. Retrieved from http://www.journalissues. org/IBSPR/

Al-Mariri,A.,\&Safi, M. (2014). Invitroantibacterial activity of several plant extracts and oils against some gram-negative bacteria, Iranian Journal of Medical Sciences, 39(1), 36-43. Retrieved from https://www.ncbi. nlm.nih.gov/pmc/articles/PMC3895893/ pdf/ijms-39-36.pdf

Al-Shabib, N. A., Husain, F. M., Ahmad, I., \& Baig, M. H. (2017). Eugenol inhibits quorum sensing and biofilm of toxigenic MRSA strains isolated from food handlers employed in Saudi Arabia. Biotechnology \& Biotechnological Equipment, 31(2), 387-396. doi: 10.1080/ 13102818.2017.1281761

Andrade, B. F. M. T., Barbosa, L. N., Probst, I. S., \& Fernandes Júnior, A. (2014). Antimicrobial activity of essential oils. Journal of Essential oil Research, 26(1), 34-40. doi: 10.1080/10412905.2013.860409
Baskaran, S. A., Kazmer, G. W., Hinckley, L., Andrew, S. M., \& Venkitanarayanan, K. (2009). Antibacterial effect of plantderived antimicrobials on major bacterial mastitis pathogens in vitro. Journal of Dairy Science, 92(4), 1423-1429. doi: 10. 3168/jds.2008-1384.

Benameur, Q., Gervasi, T., Pellizzeri, V., Pl'uchtová, M., Tali-Maama, H., Assaous, F., \& Ben-Mahdi, M. H. (2018). Antibacterial activity of Thymus vulgaris essential oil alone and in combination with cefotaxime against blaESBL producing multidrug resistant Enterobacteriaceae isolates. Natural Product Research, 33, 2647-2654. doi: 10.1080/14786419.2018.

Blair, J. M. A., Webber, M. A., Baylay, A. J., Ogbolu, D. O., \& Piddock, L. J. V. (2014). Molecular mechanisms of antibiotic resistance. Nature Reviews Microbiology, 13(1), 42-51. doi: 10.1038/nrmicro3380

Bortolin, M., Bidossi, A., De Vecchi, E., Avveniente, M., \& Drago, L. (2017). In vitro antimicrobial activity of chlorquinaldol against microorganisms responsible for skin and soft tissue infections: comparative evaluation with gentamicin and fusidic acid. Frontiers in Microbiology, June 8. Article 1039. doi: 10.3389/fmicb. 2017.01039

Bourély, C., Cazeau, G., Jarrige, N., Leblond, A., Madec, J. Y., Haenni, M., \& Gay. E. (2019). Antimicrobial resistance patterns of bacteria isolated from dogs with otitis. Epidemiology and Infection, 147(121), 1-10. doi: 10.1017/S0950268818003278

Briozzo, J., Núncez, L., Chirite, J., Herszage, L., \& D' Aquino, M. (1989). Antimicrobial activity of clove oil dispersed in a concentrated sugar solution. Journal of Applied 
Bacteriology, 66(1), 69-75. doi: 10.1111/ j.1365-2672.1989.tb02456.x

Brugnera, D. F., Liveira, M. M. M., \& Piccoli, R. H. (2011). Essential oils of Cymbopogon sp. in the control of foodborne pathogenic bacteria. Alimentos e Nutrição, 22(3), 339-343. Retrieved from http://serv-bib. fcfar.unesp.br/seer/index.php/alimentos/ article/view/1810/1810

Caraciolo, F. B., Maciel, M. A., Santos, J. B., Rabelo, M. A., \& Magalhães, V. (2012). Antimicrobial resistance profile of Staphylococcus aureus isolates obtained from skin and soft tissue infections of outpatients from a university hospital in Recife-PE, Brazil. Anais Brasileiro de Dermatologia, 87(6), 857-861. doi: 10.1590/S0365-05962012000600006

Cardoso, M. da G., Santos, M. G. L., Lima, K. R., Souza, E. P., Guimarães, L. G. L., \& Andrade, A. M. (2007). Avaliação do potencial fungitóxico do óleo essencial de Syzygium aromaticum (L.) Merr \& Perry (cravo-da-índia). Tecno-Lógica, 11(1), 1114. doi: 10.17058/tecnolog.v11i1.154

Castro, H. G., Barbosa, L. C. A., Leal, T. C. A., Souza, C. M., \& Nazareno, A. C. (2007). Crescimento, teor e composição do óleo essencial de Cymbopogon nardus (L). Revista Brasileira de Plantas Medicinais, 9(4), 55-61.

Celiktas, O. Y., Kocabas, E. E., Bedir, H. E., Vardar, S. F., Ozek, T., \& Baser, K. H. C. (2007). Antimicrobial activities of methanol extracts and essential oils of Rosmarinus oficinalis, depending on location and seasonal variations. Food Chemistry, 100(2), 553-559. doi: 10.1016/j.foodchem.2005.10.011
Clinical and Laboratory Standards Institute (2018). Performance standards for antimicrobial disk and dilution susceptibility tests for bacteria isolated from animals (5nd ed.). Wayne: CLSI Supplement VET01S. Clinical and Laboratory Standards Institute.

Córdoba, S., Vivot, W., Szusz, W., \& Albo, G. (2019). Antifungal activity of essential oils against Candida species isolated from clinical samples. Mycopathologia, 184, 615-625. doi: 10.1007/s11046-01900364-5

Costa, J. G. M., Rodrigues, F. F. G., Angélico, E. C., Silva, M. R., Mota, M. L., Santos, N. K. A.,... Lemos, T. L. G. (2005). Estudo químico-biológico dos óleos essenciais de Hyptis martiusii, Lippia sidoides e Syzigium aromaticum frente às larvas do Aedes aegypti. Revista Brasileira de Farmacognosia, 15(4), 304-309. doi: 10. 1590/S0102-695X2005000400008

Dal Pozzo, M., Santurio, D. F., Rossatto, L., Vargas, A. C., Alves, S. H., Loreto, E. S., \& Viegas, J. (2011). Activity of essential oil from spices against Staphylococcus spp. isolated from bovine mastitis. Arquivo Brasileiro de Medicina Veterinária e Zootecnia, 63(5), 1229-1232. doi: 10.15 90/S0102-09352011000500026

Dal Pozzo, M., Silva, L. É., Flores, S. D., Hartz, A. S., Rossatto, L., Castagna, V. A., Matiuzzi, C. M. (2012). Antibacterial activity of essential oil of Cinnamon and transcinnamaldehyde against Staphylococcus spp. isolated from clinical mastitis of cattle and goats. Acta Scientiae Veterinariae, 40(4), 1-5. Retrieved from https:// pesquisa.bvsalud.org/portal/resource/pt/ vti-475467 
Das, J., Pradhan, S., \& Behera, S. S. (2016). Management of otitis externa - a clinical study of 11 dogs. Intas Clinica Polivet, 17(2), 295-297. Retrieved from http:// www.indianjournals.com

Ebani, V. V., Bertelloni, F., Najar, B., Nardoni, S., Pistelli, L., \& Mancianti. (2020). Antimicrobial activity of essential oils against Staphylococcus and Malassezia strains isolated from canine dermatitis. Microorganisms, 8(252), 1-16. doi: 10.33 90/microorganisms8020252

Ebani, V. V., Nardoni, S., Bertelloni, F., Najar, B., Pistelli, L., \& Mancianti, F. (2017). Antibacterial and antifungal activity of essential oils against pathogens responsible for otitis externa in dogs and cats. Medicines, 4(21), 1-8. doi: 10.3390/ medicines 4020021

Edris, A. E. (2007). Pharmaceutical and therapeutic potentials of essential oils and their individual volatile constituents: a review. Phytotherapy Research, 21(4), 308-323. doi: 10.1002/ptr.2072

Ekpenyong, C. E., \& Akpan, E. E. (2015). Use of Cymbopogon citratus essential oil in food preservation: recent advances and future perspectives. Critical Reviews in Food Science and Nutrition, 57(12), 2541-2559. doi: 10.1080/10408398.2015.1016140

Firmino, D. F., Cavalcante, T. T. A., Gomes, G. A., Firmino, N. C. S., Rosa, L. D., Carvalho, M. G. de, \& Catunda, F. A., Jr. (2018). Antibacterial and antibiofilm activities of Cinnamomum sp. essential oil and cinnamaldehyde: Antimicrobial activities. Scientific World Journal, 2018, 7405736, 1-9. doi: $10.1155 / 2018 / 7405736$
Epi-Info 6.04b (1997). A Word Processing, Database and Statistics Program For Public Health. Center of Disease Control \& Prevention (CDC), World Health Organization, Geneva, Switzerland, Version 6.04b.

Fu, Y., Zu, Y., Chen, L., S. H. I, X., Wang, Z., Sun, S., \& Efferth, T. (2007). Antimicrobial activity of clove and rosemary essential oils alone and in combination. Phytotherapy Research, 21(10), 989-994. doi: 10. 1002/ ptr.2179

Gheller, B. G., Meirelles, A. C. F., Figueria, P. T., \& Holsbach, V. (2017). Bacterial pathogens found in dogs with external otitis and its susceptibility profiles to several antimicrobial. Pubvet, 11(2), 159-167. doi: 10.22256/pubvet. v11n2.159-167

Griffin, C.,\&Aniya, J. (2017). Otitis controversies. In M. F. S. Torres, \& P. Roudebush (Eds.), Advances in Veterinary Dermatology (pp. 210-216). Chichester, West Sussex: Wiley.

Gustafson, J. E., Liew, Y. C., Chew, S., Markham, J., Bell, H. C., Wyllie, S. G., \& Warmington, J. R. (1998). Effects of tea tree essential oils on Escherichia coli. Letters on Applied Microbiology, 26(3), 194-198. doi: 10.1046/j.1472-765x.1998.00317.x

Hammer, K. A., Carson, C. F., \& Riley, T. V. (1999). Antimicrobial activity of essential oils and other plant extracts. Journal of Applied Microbiology, 86(6), 985-990. doi: 10.1046/j.1365-2672.1999.00780.x

Hnilica, K. A. (2012). Otite Externa. Keith A. Hnilica, K. A., Patterson, A.P. In: Dermatologia de Pequenos Animais: Atlas Colorido e Guia Terapêutico (pp. 395409). Rio de Janeiro, RJ: Elsevier Health Sciences. 
Hussain, A. I., Anwar, F., \& Nigamet, P. S. (2011). Antibacterial activity of some Lamiaceae essential oils using resarzurin as an indicator of cell growth. $L W$ - Food Science and Technology, 44(4), 11991206. doi: 10.1016/j.Iwt.2010.10.005

Imane, N. I., Fouzia, H., Azzahra, L. F., Ahmed, E., Ismail, G., Idrissa, D., Noureddine, B. (2020). Chemical composition, antibacterial and antioxidant activities of some essential oils against multidrug resistant bacteria. European Journal of Integrative Medicine, 35, 1876-3820. doi: 10.1016/j. eujim.2020.101074

Kahlmeter, G., Brown, D. F. J., Goldstein, F. W., Macgowan, A. P., Mouton, J. W., Osterlund, A., Vatopoulos, A. (2003). European harmonization of MIC breakpoints for antimicrobial susceptibility testing bacteria. Journal of Antimicrobial Chemotherapy, 52(2), 145-148. doi: 10. 1093/jac/dkg312

Kaimio, M., Saijonmaa-Koulumies, L., \& Laitinen-Vapaavuori, O. (2017). Survey of otitis externa in American Cocker Spaniels in Finland. Acta Veterinaria Scandinavia, 59(14), 1-14. doi: 10.1186/s13028-0170282-3

Kamatou, G. P. P., Van Zyl, R. L., Van Vuuren, S. F., Figueiredo, A. C., Barroso, J. G., Pedro, L. G., \& Viljoen, A. M. (2008). Seasonal variation in essential oil composition, oil toxicity and the biological activity of solvent extracts of three South African Salvia species. South African Journal of Botany, 74(2), 230-237. doi: 10.1016/j. sajb.2007.08.002

Koneman, E. W., Allen, S. D., \& Janda, W. M. (2008). Diagnóstico microbiológico: texto e atlas colorido (6a ed.). Rio de Janeiro: Ed. Médica e Científica.
Kot, B., Wierzchowska, K., Grużewska, A., \& Lohinau, D. (2017). The effects of selected phytochemicals on biofilm formed by five methicillin-resistant Staphylococcus aureus. Natural Product Research, 32(11), 1299-1302. doi: 10.10 80/14786419.2017.1340282

Lang, G., \& Buchbauer, G. (2012). A review on recent research results (2008-2010) on essential oils as antimicrobials and antifungals. A review. Flavour and Fragrance Journal, 27(1), 13-39. doi: 10.1002/ffj.2082

Lee, S., Hwang, J., Kim, J., Lee, J., Kim, H. C., Rhim, H., \& Han, J. I. (2019). Biofilm production of coagulase-negative staphylococci isolated from rescued wild animals in the Republic of Korea. Acta Veterinaria Scandinavica, 61(1), 1-5. doi: 10.1186/s13028-019-0485-x

Lertsatitthanakorn, P., Taweechaisupapong, S., Aarunyanart, C., Aromdee, C., \& Khunkitti, W. (2010). Effect of citronella oil on time kill profile, leakage and morphological changes of Propionibacterium acnes. Journal of Essential Oil Research, 22(3), 270-274. doi: 10.1080/10412905.2010.9700322

Lopez-Romero, J. C., González-Ríos, H., Borges, A., \& Simões, M. (2015). Antibacterial effects and mode of action of selected essential oils components against Escherichia coli and Staphylococcus aureus. Evidence-Based Complementary and Alternative Medicine, 2015, 795435. doi: $10.1155 / 2015 / 795435$

Lorenzi, H., \& Matos, F. J. A. (2002). Plantas medicinais no Brasil: nativas e exóticas. Nova Odesa: Instituto Plantarum. 
Magiorakos, A. P., Srinivasan, A., Carey, R. B., Carmeli, Y., Falagas, M. E., Giske, C. G., Monnet, D. L. (2012). Multidrug-resistant, extensively drug-resistant and pandrugresistant bacteria: an international expert proposal for interim standard definitions for acquired resistance. Clinical Microbiology and Infection, 18(3), 268-281. doi: 10.1111/j.1469-0691.2011. 03570.x

Malayeri, H. Z., Jamshidi, S., \& Zahraei, T. S. (2010). Identification and antimicrobial susceptibility patterns of bacteria causing otitis externa in dogs. Veterinary Research Communications, 34(5), 435-444. doi: 10.1007/s11259-010-9417-y

Miguel, M. G. (2010). Antioxidant and antiinflammatory activities of essential oils: a short review. Molecules, 15(12), 92529287. doi: 10.3390/molecules 15129252

Moreira, C. A., Oliveira, L. C., Mendes, M. S., Santiago, T. de. M., Barros, E. B., \& Carvalho, C. B. M. (2012). Biofilm production by clinical Staphylococci strains from canine otitis. Brazilian Journal of Microbiology, 43(1), 371-374. doi: 10.1590/S1517-83 822012000100044

Nascimento, P. F. C., Nascimento, A. C., Rodrigues, C. S., Antoniolli, Â. O. R., Santos, P. O., Barbosa, A. M., Jr., \& Trindade, R. C. (2007). Atividadeantimicrobiana dosóleos essenciais: uma abordagem multifatorial dos métodos. Revista Brasileira de Farmacognosia, 17(1), 108-113. doi: 10. 1590/S0102-695X2007000100020

Nazzaro, F., Fratianni, F., Martino, L., Coppola, R., \& De Feo, V. (2013). Effect of essential oils on pathogenic bacteria. Pharmaceuticals, 6(12), 1451-1474. doi: 10.3390/ph6121451
Netopilova, M., Houdkova, M., Urbanova, K., Rondevaldova, J. P., Van Damme, L., \& Kokoska, L. (2020). In vitro antimicrobial combinatory effect of Cinnamomum cassia essential oil with 8 hydroxyquinoline against Staphylococcus aureus in liquid and vapour phase. Journal of Applied Microbiology, 129(4), 906-915. doi: 10. 1111/jam.14683

Nostro, A., Sudano, R. A., Bisignano, G., Marino, A., Cannatelli, M. A., Pizzimenti, F. C.,... Blanco, A. R. (2007). Effects of oregano, carvacrol and thymol on Staphylococcus aureus and Staphylococcus epidermidis biofilms. Journal of Medical Microbiology, 6(4), 519-523. doi: 10.1099/jmm.0.46804-0

O'Bryan, C. A., Pendleton, S. J., Crandall, P. G., \& Ricke, S. C. (2015). Potential of plant essential oils and their components in animal agriculture - in vitro studies on antibacterial mode of action. Frontiers in Veterinary Science, 2(35), 1-8. doi: 10.3389/fvets.2015.00035

Oliveira, J. B., Teixeira, M. A., Paiva, L. F., Oliveira, R. F., Mendonça, A. R., \&Brito, M. J. A. (2019). In vitro and in vivo antimicrobial activity of Cymbopogon citratus (DC.) stapf. against Staphylococcus spp. isolated from newborn babies in an intensive care unit. Microbial Drug Resistance, 25(10), 14901496. doi: $10.1089 / \mathrm{mdr} .2018 .0047$

Oliveira, M. A. C., Borges, A. C., Brighenti, F. L., Salvador, M. J., Gontijo, A. V. L., \& Koga-Ito Cymbopogon, C. Y. (2017). Cymbopogon citratus essential oil: effect on polymicrobial caries-related biofilm with Iow cytotoxicity Brazilian Oral Research, 31(89), 1-12. doi: 10.1590/1807-3107bor2017 
Oliveira, V. B., Ribeiro, M. G., Almeida, A. C. S., Paes, A. C., Condas, L. A. Z., Lara, G. H. B., Listoni, F. J. P. (2012). Etiologia, perfil de sensibilidade aos antimicrobianos e aspectos epidemiológicos na otite canina: estudo retrospectivo de 616 casos. Semina: Ciências Agrárias, 33(6), 2367-2374. doi: 10.5433/1679-0359.20 12 v33n6p2367

Opalchenova, G., \& Obreshkova, D. (2003). Comparative studies on the activity of basil - an essential oil from Ocimum basilicum L. against multidrug resistant clinical isolates of the genera Staphylococcus, Enterococcus and Pseudomonas by using different test methods. Journal of Microbiological Methods, 54(1), 105-110. doi: 10.1016/s0167-7012(03)00012-5

Orchard, A., \& Van Vuuren, S. (2017). Commercial essential oils as potential antimicrobials to treat skin diseases. Evidence-Based Complementary and Alternative Medicine, 2017: 4517971. doi: $10.1155 / 2017 / 4517971$

Ortega-Cuadros, M., Tofiño-Rivera, A. P., Merini, L. J., \& Martínez-Pabon, M. C. (2018). Antimicrobial activity of Cymbopogon citratus (Poaceae) on Streptococcus mutans biofilm and its cytotoxic effects. Revista Biologia Tropical, 66(4), 1519-29. doi: $10.15517 /$ rbt.v66i4.33140

Oussalah, M., Caillet, S., Saucier, L., \& Lacroix, M. (2006). Antimicrobial effects of selected plant essential oils on the growth of a Pseudomonas putida strains isolated from meat. Meat Science, 73(2), 236-244. doi: 10.1016/j.meatsci.2005.11.019

Penna, B., Varges, R., Martins, G. M., Martins, R. R., \& Lilenbaum, W. (2010).
Species distribution and antimicrobial susceptibility of Staphylococci isolated from canine otitis externa. Veterinary Dermatology, 21(3), 292-296. doi: 10.11 $11 / \mathrm{j} .1365-3164.2009 .0084$

Petrov, V., Mihaylov, G., Tsachev, I., Zhelev, G., Marutsov, P., \& Koev, K. (2013). Otitis externa in dogs: microbiology and antimicrobial susceptibility. Revue de Médecine Vétérinaire, 164(1), 18-22. Retrieved from https://www.revmedvet. com/2013/RMV164_18_22.pdf

Reichling, J., Schnitzler, P., Suschke, U., \& Saller, R. (2009). Essential oils of aromatic plants with antibacterial, antifungal, antiviral, and cytotoxic properties-an overview. Forschende Komplementarmedizin, 16(2), 79-90. doi: 10.1159/000207196

Sahal, G., Woerdenbag, H. J., Hinrichs, W. L. J., Visser, A., Tepper, P. G., Quax, W. J., \& Bilkay, I. S. (2020). Antifungal and biofilm inhibitory effect of Cymbopogon citratus (lemongrass) essential oil on biofilm forming by Candida tropicalis isolates; an in vitro study. Journal of Ethnopharmacology, 246, 1-9. doi: 10. 1016/j.jep.2019.112188.

Scherer, C. B., Botoni, L. S., Coura, F. M., Silva, R. O., Santos, R. D., Heinemann, M. B., \& Costa-Val, A. P. (2018). Frequency and antimicrobial susceptibility of Staphylococcus pseudintermedius in dogs with otitis externa. Ciência Rural, 48(4), e20170738. doi: 10.1590/0103$8478 \mathrm{cr} 20170738$

Silva, B. C. J. de, Hossain, S., Wimalasena, S. H. M. P., Pathirana, H. N. K. S., Dahanayake, P. S., \& Heo, G. J. (2018). Comparative in vitro efficacy of eight essential oils as 
antibacterial agents against pathogenic bacteria isolated from pet-turtles. Veterinarni Medicina, 63, 335-343. doi: 10.17221/142/2017-VETMED.

Suzuki, H., Flemming, J. S., \& Traad, M. E. (2008). Uso de óleos essenciais na alimentação de leitões. Ciências Agrárias e Ambientais, 6(4), 519-526. Retrieved from https://periodicos.pucpr. br/index.php/cienciaanimal/article/view File/11648/10985

Swamy, M. K., Akhtar, M. S., \& Sinniah, U. R. (2016). Antimicrobial properties of plant essential oils against human pathogens and their mode of action: an updated review. Evidence-Based Complementary and Alternative Medicine, 2016, 3012462. doi: 10.1155/2016/3012462

Sykes, J. E., Nagle, T. N., \& White, S. D. (2014). Pyoderma, otitis externa, and otitis media. In J. E. Sykes (Ed.), Canine and Feline Infectious Diseases, (pp. 800-813). St. Louis: W.B. Saunders.
Varshney, J. P. (2016). Therapeutic management of otitis externa due to Malassezia pachydermatis and Staph. Infection - a clinical study of 20 dogs. Intas Polivet, 17(2), 300-301. Retrieved from https://www. indianjournals.com/ijor. aspx?target=ijor:ipo\&volume=17\&issue= 2\&article $=029$

Wattanasatcha, A., Rengpipat, S., \& Wanichwecharungruang, S. (2012). Thymol nanospheres as an effective antibacterial agent. International Journal of Pharmaceutics, 434(1-2), 360-365. doi: 10.1016/j.ijpharm.2012.06.017

Yadav, M. K., Chae, S.-W., Im, G. J., Chung, J.W., \& Song, J.-J. (2015). Eugenol: a phytocompound effective against methicillinresistant and methicillin- sensitive Staphylococcus aureus clinical strain biofilms. PLoS One, 10(3), e0119564. doi: $10.1371 /$ journal.pone.0119564 
